Article

\title{
What Drives Low-Severity Fire in the Southwestern USA?
}

\author{
Sean A. Parks ${ }^{1, *(1)}$, Solomon Z. Dobrowski ${ }^{2}$ and Matthew H. Panunto ${ }^{3}$ \\ 1 Aldo Leopold Wilderness Research Institute, Rocky Mountain US Forest Service, 790 E. Beckwith Ave., \\ Missoula, MT 59801, USA \\ 2 W.A. Franke College of Forestry and Conservation, Department of Forest Management, University of \\ Montana, 32 Campus Dr., Missoula, MT 59812, USA; solomon.dobrowski@umontana.edu \\ 3 Missoula Fire Sciences Laboratory, Rocky Mountain Research Station, US Forest Service, 5775 Hwy 10 W, \\ Missoula, MT 59808, USA; mpanunto@fs.fed.us \\ * Correspondence: sean_parks@fs.fed.us; Tel.: +1-406-542-4182
}

Received: 27 February 2018; Accepted: 21 March 2018; Published: 24 March 2018

\begin{abstract}
Many dry conifer forests in the southwestern USA and elsewhere historically (prior to the late 1800's) experienced fairly frequent surface fire at intervals ranging from roughly five to 30 years. Due to more than 100 years of successful fire exclusion, however, many of these forests are now denser and more homogenous, and therefore they have a greater probability of experiencing stand-replacing fire compared to prior centuries. Consequently, there is keen interest in restoring such forests to conditions that are conducive to low-severity fire. Yet, there have been no regional assessments in the southwestern USA that have specifically evaluated those factors that promote low-severity fire. Here, we defined low-severity fire using satellite imagery and evaluated the influence of several variables that potentially drive such fire; these variables characterize live fuel, topography, climate (30-year normals), and inter-annual climate variation. We found that live fuel and climate variation (i.e., year-of-fire climate) were the main factors driving low-severity fire; fuel was $\sim 2.4$ times more influential than climate variation. Low-severity fire was more likely in settings with lower levels of fuel and in years that were wetter and cooler than average. Surprisingly, the influence of topography and climatic normals was negligible. Our findings elucidate those conditions conducive to low-severity fire and provide valuable information to land managers tasked with restoring forest structures and processes in the southwestern USA and other regions dominated by dry forest types.
\end{abstract}

Keywords: fire severity; burn severity; wildland fire; forests; fire regime; fire refugia

\section{Introduction}

Wildland fire is an integral component of most dry conifer forest ecosystems in the southwestern USA and elsewhere [1]. Analyses of fire scarred trees indicate that most dry conifer forests in the southwest USA historically (i.e., prior to the late 19th century) experienced frequent surface fire and less frequent mixed-severity fire at intervals ranging from roughly five to thirty years [2-4]. However, as a result of fire exclusion policies that reduced fire frequency and area burned after the late 19th century [5,6], many dry conifer forests in the southwestern USA are denser and more homogenous compared to the pre-settlement era $[7,8]$. Consequently, there is growing concern that some dry forests are at risk of burning at higher severities (i.e., stand-replacing) than occurred in past centuries $[9,10]$. Recent research suggests this is indeed the case [11-13].

Stand-replacing fire in dry conifer forests has caused substantial concern about enduring conversions to non-forest. It is evident, for example, that the regeneration of dry conifer species (e.g., ponderosa pine) becomes more limited with increasing fire severity, increasing distance to seed 
source, and at sites with drier biophysical characteristics [14-16]. Short-interval high-severity fire (i.e., reburning at high-severity) in some dry forests also leads to post-fire successional trajectories that substantially differ from the pre-fire conditions, raising additional concern about altered successional trajectories and conversion to non-forest [17-19]. Although the drivers and consequences of high-severity fire are being increasingly studied, little to no research has been conducted that specifically focuses on the factors that promote low-severity fire, particularly in regions dominated by dry conifer forest that historically experienced frequent surface fire. A better understanding of those factors promoting low-severity fire could assist managers interested in reintroducing such fire to dry conifer forests in the southwest USA and elsewhere. Furthermore, identifying factors that promote low-severity fire could help identify biophysical settings in need of restoration treatments (e.g., prescribed fire and mechanical thinning) that will increase the likelihood of surface fire, thereby lowering the likelihood of stand-replacing fire and potential fire-facilitated conversions to non-forest.

Indeed, many dry conifer forests in the southwestern USA are in need of restoration in order to increase their resilience (i.e., reduce the probability of stand-replacing fire and associated transition to non-forest) [20,21]. Restoration treatments usually refer to mechanical thinning and prescribed fire [22], but it has been pointed out that the pace and scale of such treatments are inadequate in addressing the large area in need of restoration due to logistical, legal, and physical (i.e., topography) constraints [23]. However paradoxical it may seem, wildland fire itself has also been espoused as an effective method for increasing the resilience of dry conifer forests [24,25]. Reintroducing stand-replacing fire is obviously counterproductive for dry conifer forests, and consequently, Allen et al. [26] recommend, among other restoration treatments, the reintroduction of low-severity fire in such forests. This said, uncertainty about the biophysical settings in which low-severity fire is probable, and under what weather conditions, likely precludes the reintroduction of such fire in most cases (cf. [27]). This is a substantial knowledge gap given that low-severity fire was common in such forests prior to European settlement and the growing interest in restoring surface fire to dry conifer forests. Excluding studies involving fire refugia, which focus on unburned or low-severity patches within a matrix of moderateto high-severity fire [28,29], little-to-no research has been conducted that specifically focuses on the drivers of low-severity fire in dry conifer forests such as those found in the southwestern USA.

The overarching goal of our study was to identify the most important factors driving low-severity fire in the southwestern USA. We measured fire severity using a satellite-inferred metric of fire-induced change, the relativized burn ratio [30]. We evaluated the relative influence of several factors driving low-severity fire including live fuel, topography, climate (30-year normals), and inter-annual climate variation (i.e., year-of-fire climate). We were also interested in functional relationships between important variables and low-severity fire, thereby providing managers with information pertaining to the biophysical and year-of-fire climatic conditions that promote low-severity fire. Consequently, our results will be highly relevant and timely to land managers interested in restoring fire regimes in the southwestern USA and other regions dominated by dry conifer forest.

\section{Materials and Methods}

\subsection{Study Area}

We conducted our study in the southwestern USA because of the high prevalence of dry conifer forest and the historical dominance of frequent, low-severity fire [31]. Specifically, we focused on the Arizona-New Mexico ecoregion (plus a 10-km buffer; 150,747 $\mathrm{km}^{2}$ ) as defined by The Nature Conservancy [32] (Figure 1). Elevation ranges from 1053 to $3756 \mathrm{~m}$ (mean across ecoregion $=1986 \mathrm{~m}$ ). The ecoregion is climatically diverse; mean annual temperature ranges from 0.5 to $17.2{ }^{\circ} \mathrm{C}$ $\left(\right.$ mean $\left.=11.1^{\circ} \mathrm{C}\right)$ and mean annual precipitation from 16.7 to $121.1 \mathrm{~cm} /$ year $($ mean $=40.6 \mathrm{~cm} /$ year $)$ [33] . Almost half $(48 \%)$ of the precipitation occurs in the summer (July-September) due to monsoonal storms [34]. The vegetation is also diverse; dominant forest types include pinyon-juniper woodland $(22.4 \%$ of study area) and ponderosa pine woodland and savannah $(12.7 \%)$ [31]. Other forest 
types such as mixed conifer, spruce-fir, and conifer-oak represent a fairly small proportion of the study area. Our study does not include non-forested vegetation (see below) and is therefore not described here. The proportional coverage of vegetation communities within the burned areas can be characterized as follows: ponderosa pine $=52 \%$, pine-oak types $=20 \%$ (includes Arizona pine, alligator juniper, and Emory oak), mixed-conifer types $=15 \%$ (includes Douglas fir and white fir), subalpine types $=5 \%$ (includes Engelmann spruce and subalpine fir), riparian = 5\% (includes black cottonwood), and pinyon-juniper $=4 \%$ [31]. The fire season runs from early May through late-August (USDA Forest Service 2013), although fires are less likely after early July due to rains associated with monsoonal storms from the Gulf of Mexico [35,36]. Fires in this region were generally characterized as occurring frequently and at a low-severity prior to European settlement, although it is recognized that fire severity varies with elevation and topography [5,37]. Extensive cattle and sheep grazing began in the 1880s, which substantially reduced fine fuel amount and continuity and caused a decrease in fire frequency [38]. Continued fire exclusion via direct fire suppression has contributed to increases in tree density and shade-tolerant species, thereby heightening concern about uncharacteristically severe fire and altered post-fire successional trajectories $[20,39,40]$.

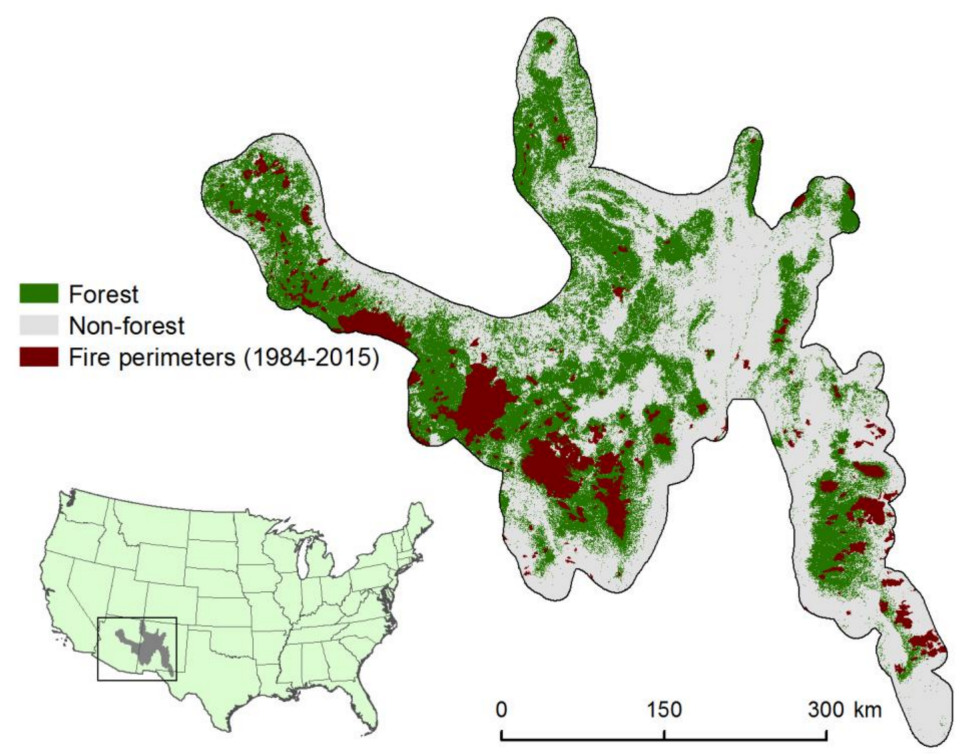

Figure 1. Study area map shows the distribution of forest, non-forest, and fire in our study area (the Arizona-New Mexico Mountains ecoregion). Inset shows this ecoregion's location in the context of the contiguous USA.

\subsection{Data}

Fire severity was measured using the relativized burn ratio (RBR), an index (resolution: 30-m) that quantifies the difference between pre- and post-fire Landsat thematic mapper (TM), enhanced thematic mapper plus (ETM+), and operational land imager (OLI) satellite data. The RBR has a high correspondence to field-based measures of severity such as the composite burn index $\left(\mathrm{CBI} ; r^{2}=0.71\right)$ [30]. We classified the RBR data into binary categories representing low-severity $(R B R \leq 116)$ and other severity $(R B R>116)$ (Figure $2 b)$. The $R B R=116$ value corresponds to the average threshold between low and moderate severity for the nine fires analyzed in the southwestern USA by Parks et al. [30]; a similar thresholding approach was used by Dillon et al. [41] in their analysis involving high-severity fire. Satellite imagery used to generate RBR was obtained from the Monitoring Trends in Burn Severity program (MTBS) [42], which distributes fire and satellite data for fires $\geq 400$ ha for the years 1984-2015. RBR was calculated using the 'dNBR offset', which accounts for differences due to phenology or precipitation between the pre- and post-fire imagery by subtracting the average 
delta normalized burn ratio (dNBR) of pixels outside the burn perimeter [43]; this can be important when comparing severity among fires [30].

We evaluated 13 explanatory variables in describing low-severity fire that can be categorized into four groups characterizing live fuel, topography, climate (30-year normals), and inter-annual climate variation (i.e., year-of-fire climate) (Table 1). The fuel group is comprised of three vegetation indices derived from satellite data: NDVI, NDMI, and EVI (Table 1) (resolution $=30-\mathrm{m}$ ). These indices were generated using pre-fire imagery distributed by MTBS. NDVI is an index of vegetation productivity and biomass [44]. NDMI is a measure of vegetation moisture and is frequently used in drought monitoring, and because of its sensitivity, it is also key in assessing wildfire potential and severity [45,46]. EVI is an alternative index of vegetation productivity, but, whereas NDVI is chlorophyll sensitive, EVI is more responsive to canopy structural variations (i.e., leaf area index, canopy type, plant physiognomy, and canopy architecture) [47] (Figure 2).

Table 1. Variables evaluated as predictors in modeling the probability of low-severity fire in forests of the southwestern USA.

\begin{tabular}{|c|c|c|c|}
\hline Group & Variable Name & Description & Source \\
\hline \multirow{3}{*}{ Live fuel } & NDVI & $\begin{array}{l}\text { Normalized differenced vegetation index. } \\
\text { Calculated using pre-fire imagery distributed } \\
\text { by the Monitoring Trends in Burn Severity } \\
\text { (MTBS) program [41]. }\end{array}$ & Pettorelli et al. [44] \\
\hline & NDMI & $\begin{array}{l}\text { Normalized differenced moisture index. } \\
\text { Calculated using pre-fire imagery distributed } \\
\text { by MTBS [41]. }\end{array}$ & McDonald et al. [46] \\
\hline & EVI & $\begin{array}{l}\text { Enhanced vegetation index. Calculated using } \\
\text { pre-fire imagery distributed by MTBS [41]. }\end{array}$ & Huete [47] \\
\hline \multirow{4}{*}{ Topography } & DISS & $\begin{array}{l}\text { Dissection index with a } 450 \mathrm{~m} \text { radius. DISS is } \\
\text { a measure of topographic complexity. }\end{array}$ & Evans [48] \\
\hline & TPI & $\begin{array}{l}\text { Topographic position index. TPI is a measure } \\
\text { of valley bottom vs. ridge top and measures } \\
\text { the elevational difference (meters) between } \\
\text { each pixel and an annulus with } \\
\text { a } 2000-\mathrm{m} \text { radius. }\end{array}$ & NA \\
\hline & SRAD & $\begin{array}{l}\text { Potential solar radiation, as calculated using } \\
\text { the SOLPET6 model. }\end{array}$ & Flint et al. [49] \\
\hline & Slope & Slope angle & NA \\
\hline \multirow{3}{*}{ Climate } & CMD & $\begin{array}{l}\text { Climatic moisture deficit [49]. Mean over the } \\
\text { 1981-2010 time period. }\end{array}$ & \multirow{3}{*}{$\begin{array}{l}\text { Wang et al. [50]; } \\
\text { https://adaptwest. } \\
\text { databasin.org/ }\end{array}$} \\
\hline & ET & $\begin{array}{l}\text { Evapotranspiration (i.e., Eref-CMD). } \\
\text { Mean over the 1981-2010 time period. }\end{array}$ & \\
\hline & MAT & $\begin{array}{l}\text { Mean annual temperature. Mean over the } \\
\text { 1981-2010 time period. }\end{array}$ & \\
\hline \multirow{3}{*}{$\begin{array}{l}\text { Inter-annual climate } \\
\text { variation }\end{array}$} & Temp.z & $\begin{array}{l}\text { Mean June temperature for the year in which } \\
\text { the fire occurred. Converted to a } z \text {-score. }\end{array}$ & \multirow{3}{*}{$\begin{array}{l}\text { ClimateNA software } \\
\text { package; Wang et al. [50] }\end{array}$} \\
\hline & ET.z & $\begin{array}{l}\text { Mean June evapotranspiration for the year in } \\
\text { which the fire occurred. Converted to } \\
\text { a } z \text {-score. }\end{array}$ & \\
\hline & CMD.z & $\begin{array}{l}\text { Mean June climatic moisture deficit for the } \\
\text { year in which the fire occurred. Converted to } \\
\text { a } z \text {-score. }\end{array}$ & \\
\hline
\end{tabular}



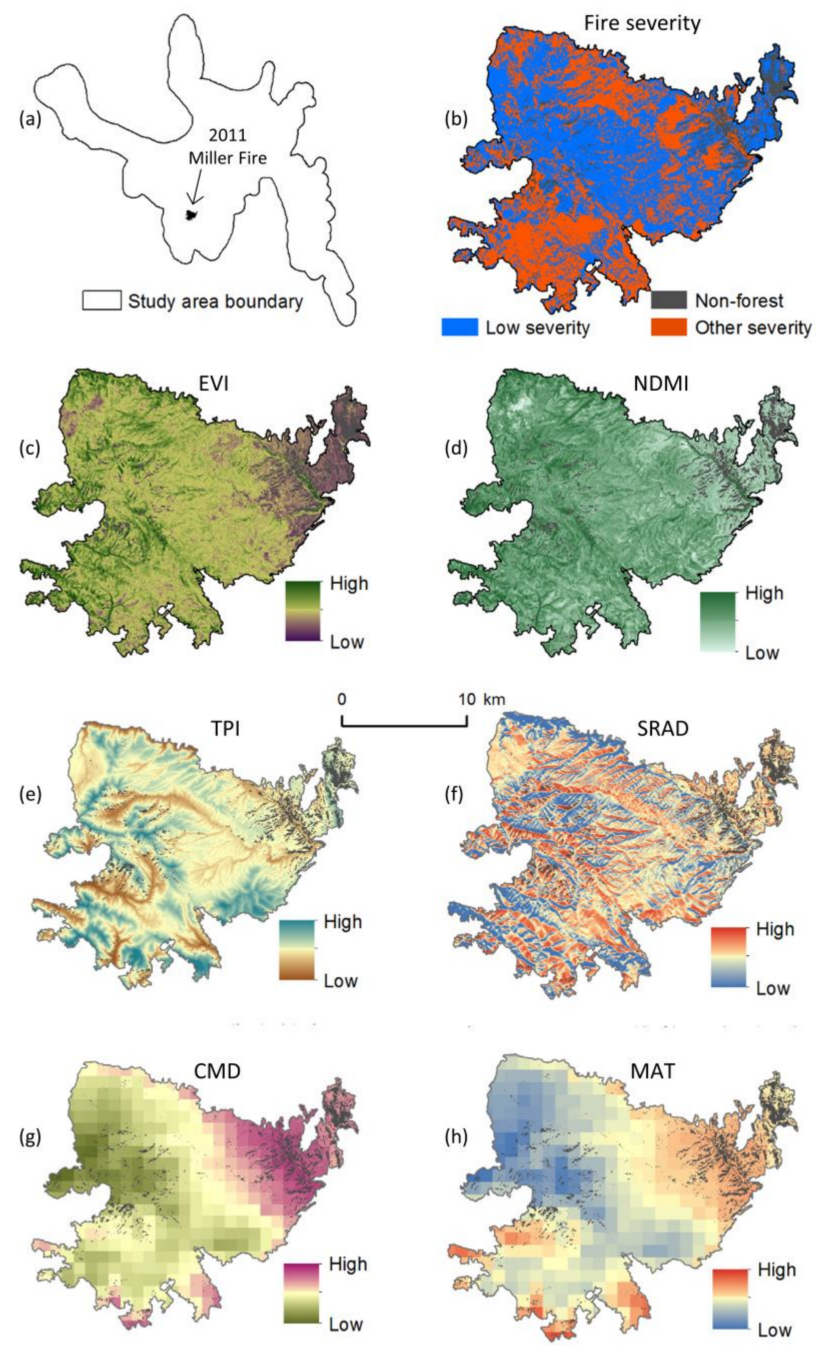

Figure 2. Example shows one of the $>400$ fires evaluated. Location of the 2011 Miller fire within the study area (a). Fire severity for the 2011 Miller Fire (b). Examples of the variables we used to represent pre-fire fuel (c,d), topography (e,f), and climate (g,h) for the 2011 Miller Fire. Inter-annual climate variation is not shown here because such variables are more indicative of temporal variability as opposed to spatial variability for individual fires. EVI: enhanced vegetation index; NDMI: normalized differenced moisture index; TPI: topographic position index; SRAD: solar radiation; CMD: climatic moisture deficit; MAT: mean annual temperature.

Climate is represented by three variables (resolution $=1-\mathrm{km}$ ): climatic moisture deficit (CMD), reference evapotranspiration minus CMD, hereafter referred to as evapotranspiration (ET), and mean annual temperature (MAT) [50] (Table 1; Figure 2). These variables characterize spatial variability and represent climate normals over the 1981-2010 time period (they do not vary annually) and have been identified as predictors of wildland fire in several studies [51-53].

Inter-annual climate variation is represented by three 'year-of-fire' variables: Temp.z, CMD.z, and ET.z (Table 1). These variables represent the $z$-scores for the month of June in the year in which each fire burned; June experiences the highest fire activity on average in the southwestern USA [54]. As such, Temp.z represents mean temperature for the month of June in the year in which the fire burned. CMD.z represents climatic moisture deficit and ET.z represents evapotranspiration for the month of June in the year in which the fire burned. These variables (resolution $=1-\mathrm{km}$ ) were generated using the ClimateNA software package (version 5.10) [50]. Recent studies have used similar variables representing climate variation in evaluations of fire severity $[55,56]$. All variables representing climate 
variation were converted to $z$-scores using the per-pixel mean and standard deviation for the month of June over a 30-year time period (1986-2015). Z-scores therefore represent the value in the month of June in terms of standard deviations away from the June mean.

\subsection{Sampling Design and Statistical Model}

We sampled fires that occurred from 1984-2015. We only sampled pixels identified as forest (i.e., forest, woodland, and savanna), as defined by a combination of landscape level vegetation products that include Landfire's [31] Existing Vegetation Cover (EVC), Environmental Site Potential (ESP), and the Landsat Time Series Stacks-Vegetation Change Tracker (LTSS-VCT) [57]. From the full set of burned forested pixels, we generated an initial 5\% random sample, but then removed all pixels $<100 \mathrm{~m}$ from the fire perimeter to reduce edge effects common at fire boundaries [58]. Although predictor variables ranged in resolution from $30-\mathrm{m}$ to $1-\mathrm{km}$, all extractions were conducted using the native resolution of the response variable (30-m).

We produced a logistic regression model (family = binomial) describing low-severity fire (binary response) as a function of the 13 variables representing live fuel, topography, climate, and inter-annual climate variation (Table 1). We used a five-fold cross-validated procedure in which $80 \%$ of the fires (not the samples/pixels) were used to build a model and the remaining $20 \%$ of the fires were used to test the model; this ensures our cross-validation was spatially and temporally structured and that our model validation and inferences are not a result of autocorrelation common in satellite-inferred severity data [58-60]. For each of the five folds, we calculated the area under curve (AUC) statistic derived from the receiver operating characteristic curve of the full model (includes all 13 explanatory variables). We then compared this AUC to the AUC of additional models in which each variable was excluded. The AUC using the test data was averaged over the five folds. If the cross-validated AUC increased when a variable was removed, it was an indication that the variable did not provide unique information that improved model fit. As such, we removed the variable that resulted in the largest AUC increase when it was removed from the model. We then repeated this procedure until all variables resulted in a decrease in the cross-validated AUC when they were individually removed from the model. All statistical analyses were conducted using the $R$ statistical program [61]. The cross-validation and stepwise variable selection procedures follow that of Parks et al. [62].

The cross-validated stepwise procedure we employed has some advantages compared to approaches that do not hold out independent data. For example, this procedure reduces the possibility of model overfitting and avoids falsely inflating our model skill (i.e., AUC statistic). Because our test data are independent_-data from fires used to build the model (i.e., training data) were not used for model validation and variable selection (i.e., testing data)—our models are spatially and temporally transferable. Variables are retained based solely on whether or not they improve model fit; even if retained variables are correlated, they still possess unique information that improves the model.

Once the final set of variables was identified using the procedure described above, we calculated the relative influence of each variable group (fuel, topography, climate, and climate variation). This was achieved using a five-fold cross validation while excluding each group of variables. Specifically, we compared the five-fold cross validated AUC of the final model to models that excluded variables characterizing fuel, topography, climate, and inter-annual climate variation. Small decreases in AUC (compared to the final model) for any particular variable group are interpreted as having little influence, whereas sizeable decreases in AUC are interpreted as having large influence. The specific equation is as follows:

$$
\text { Relative influence }_{i}=\frac{\text { AUC.full }- \text { AUC.no.var }}{i}=100
$$

where AUC.full is the AUC of the full model, AUC.no.var ${ }_{i}$ is the AUC of the model excluding any particular variable group, and $i$ represents one of the variable groups. 
We produced response curves describing the probability of low-severity fire as a function of all variables retained in the final model. To do so, we built individual logistic regression models (family $=$ binomial) for each variable and plotted the response curves.

\section{Results}

We included data from over 400 fires that burned over $12,000 \mathrm{~km}^{2}$ of forest to inform our model describing the probability of low-severity fire. The spatially and temporally cross-validated AUC was 0.701. Live fuel was the most influential factor driving low-severity fire (relative influence $=70.0 \%$ ). This was followed by inter-annual climate variation (relative influence $=28.6 \%$ ). The influence of topography and climate was negligible $(0.9 \%$ and $0.5 \%$, respectively). Our final model included eight variables that remained after the cross-validated stepwise procedure: EVI, NDMI, TPI, SRAD, ET, TEMP.z, ET.z, and CMD.z.

The response curves show a negative relationship between low-severity fire and both measures of fuel; that is, the probability of low-severity fire decreases with increasing fuel (Figure 3). Low-severity fire has a negative relationship with both Temp.z and CMD.z, so low-severity fire is more likely in years in which the June temperature and climatic moisture deficit are lower than average (i.e., $z$-scores $<0$ ) compared to higher than average ( $z$-score $>0)$. Finally, the relationship between low-severity fire and ET.z is positive, meaning the probability of low-severity fire increased with June evapotranspiration. We do not show the functional relationships with SRAD, TPI, and ET because the relative influence of these variables is less than $1 \%$ each.
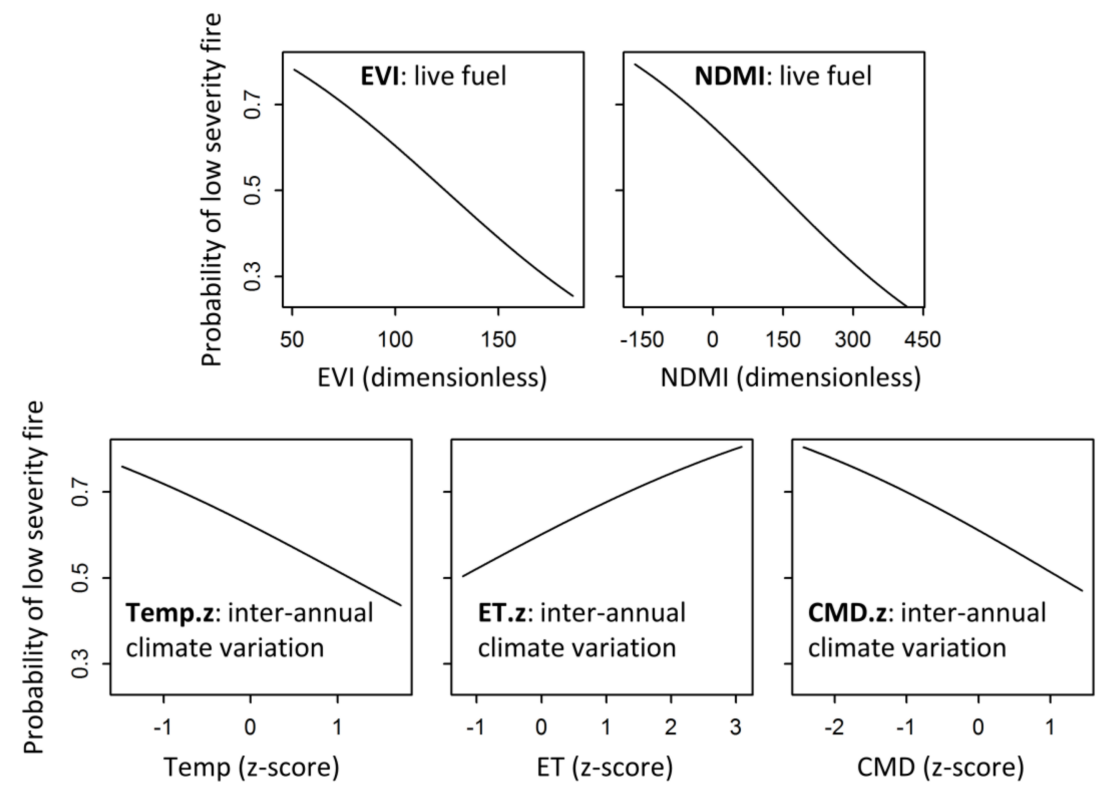

Figure 3. Functional relationships depict the probability of low-severity fire as a function of live fuels and inter-annual climate variation. Each of these was produced with a logistic regression with only the variable of interest. EVI: enhanced vegetation index; NDMI: normalized differenced moisture index; Temp.z: temperature z-score; ET.z: evapotranspiration z-score; CMD.z: climatic moisture deficit $z$-score. Functional relationships for TPI, SRAD, and ET are not shown since the relative influence of these variables is less than $1 \%$.

\section{Discussion}

Our study pertains to those factors responsible for low-severity fire, thereby providing a different lens with which to view fire compared to the numerous studies that focus on the drivers and distribution of high-severity fire $[37,41,56,62-64]$. Specifically, because our study identifies the drivers of, and their relationship to, low-severity fire, we fill a critical information gap for dry forested regions 
in which prescribed fire and wildland fire managed for resource benefit are often espoused as forest restoration strategies $[26,65,66]$. This contrasts from those evaluations of high-severity fire, which often underscore the legitimate negative ecological and social impacts of such fire including the potential for altered successional trajectories and conversion to non-forest, particularly in dry forested ecosystems such as those found in the southwestern USA and elsewhere $[17,39,67]$.

It is not entirely clear whether the factors that control low-severity fire can be inferred from studies of high-severity fire. Consequently, we suggest that our explicit attention to low-severity fire avoids ambiguity and potential misinterpretations that could arise from making inferences from high-severity fire studies. This is particularly important given that we focused on forests of the southwestern USA that historically experienced frequent surface fire prior to the late 19th century $[4,5]$. Moreover, our evaluation included four main drivers of low-severity fire (live fuel, topography, climate, and inter-annual climate variation), whereas most fire severity studies to date have included only one to three of these factors (e.g., [41,51,68]) (but see Parks et al. [62]). Lastly, many evaluations of high-severity fire included a limited number of fires (e.g., $[51,69,70]$ ), which potentially prevents generalizing their findings over broader regions; in contrast, our study included data from over 400 fires.

Live fuel was by far the most important variable group promoting low-severity fire (relative influence $=70.0 \%$ ); Parks et al. [62] also found that fuel was most important in their evaluation of high-severity fire in the western USA. Other studies that used proxies for fuel (e.g., vegetation type or canopy cover) have also highlighted the influence of this factor in driving fire severity [71,72]. Moreover, we show that the probability of low-severity fire increased with decreasing levels of live fuel, as represented by EVI and NDMI (Figure 3). This result supports the findings of numerous studies based on field data [40,73], fire simulation modelling [74,75], and satellite-inferred severity metrics $[59,76,77]$ that showed a reduction in fuel resulted in lower severity fire.

Year-of-fire climate (i.e., inter-annual climate variation) was the second most important variable group driving low-severity fire (relative influence $=28.6 \%$ ). Keyser and Westerling [56], in their evaluation of high-severity fire, also highlighted the importance of climate variation. Importantly, our finding that the probability of low-severity fire increased with decreasing year-of-fire temperature and climatic moisture deficit is consistent with the findings of Abatzoglou et al. [55], who found a positive correlation between fire severity and year-of-fire fuel aridity. We find it notable that the climate metrics we used (departures from the mean value for the month of June, which are at a fairly coarse temporal resolution) exhibited a rather high relative influence. This suggests that near-term wildland fire forecasts, which currently address only area burned or number of large fires based on expected weather and other factors [78,79], could potentially forecast fire severity, thereby providing fire managers and others with a more complete prediction of the upcoming fire season.

Surprisingly, topography and climate (30-year normals representing spatial variability) had a negligible influence on the prevalence of low-severity fire (relative influence $=0.9 \%$ and $0.5 \%$, respectively). This contrasts with a multitude of studies that showed topography is moderately to highly important in controlling fire severity (e.g., $[41,51,68,72,80]$ ). Likewise, recent studies conducted at scales ranging from individual fires to numerous fires across large regions have concluded that climate is related to fire severity [51,52,81]. We posit here, similar to Parks et al. [62], that topography and climate are indirect measures of fuel, and because we explicitly include fuel in our model, topography and climate are regarded as inconsequential. Indeed, Dillon et al. [41] acknowledged that topography was likely serving as a proxy for variation in fuel and other factors that were not accounted for in their study. Regardless, it is worth noting that Parks et al. [62], who evaluated high-severity fire, found substantial ecoregional variation in terms of the relative influence of topography and climate, suggesting that the findings presented here might not be generalizable to other regions.

The results of our study can be considered in relation to the growing body of literature pertaining to fire refugia [82-85]. Most fire refugia studies involve the study of unburned or low-severity remnants within a matrix of high-severity effects (e.g., [86]) or are focused on regions that are inherently 
characterized by mixed-severity and stand-replacing fire regimes (e.g., [87]). For the most part, these studies have not investigated those factors that create or promote the creation of fire refugia, but have instead focused on characterizing their prevalence and spatial patterns. This said, a limited number of studies have evaluated the factors promoting the creation of fire refugia; they found that topography and fire weather were important drivers [28,29]. Nevertheless, we suggest more research is needed to gain a better understanding of the factors that promote the creation of fire refugia and promote low-severity fire in general.

Producing statistical models of low-severity fire (or any severity fire) is challenging for several reasons. Remotely sensed metrics of fire severity are imperfect estimates of complex processes [88]. Nonetheless, such metrics are arguably the most consistent and appropriate for describing and analyzing fire severity over large landscapes and across multi-decadal timeframes. Furthermore, we used satellite indices to characterize fuel, but this approach generally describes live overstory vegetation and does not account for sub-canopy live and dead surface fuels that influence fire severity [89]. However, adequately characterizing live and dead sub-canopy fuel over large landscapes is difficult, if not impossible. Also, we used climate departures from the month with the highest average fire activity (June) to broadly characterize weather conditions conducive to fire. Fire severity, however, is known to vary with daily to hourly fluctuations in weather conditions [62,69]. Future investigations of low-severity fire could employ satellite fire detection data to infer the day that each pixel burned [90,91] and incorporate daily fire weather into their models (cf. [28,92]). Lastly, all else being equal, fire behavior and effects are different depending on the direction of fire spread (e.g., heading vs. flanking fire) [93], and at this time, we cannot capture this directional effect in our models.

\section{Conclusions}

Our study elucidates those conditions conducive to low-severity fire. Fuel and inter-annual climate variation (i.e., year-of-fire climate) were the dominant factors controlling the prevalence of low-severity fire, although the relative influence of fuel was $\sim 2.4$ times greater than that of climate variation. The probability of low-severity fire increased at lower levels of fuels and in years that were cooler and wetter than average. The influence of topography and climate (30-year normals representing a spatial gradient) was negligible. These findings support the notion that fuel treatments will likely increase the probability of low-severity fire $[40,73,94]$. Nevertheless, the influence inter-annual climate variation should not be discounted. Low-severity fire was more prevalent in cooler and wetter fire seasons (than average), which provides rationale for allowing more fires to burn (i.e., less aggressive fire suppression) in non-extreme years. These wildland fires are efficient means to reduce fuel loads, which has important consequences given that fuels are the prominent driver of high-severity fire [62]. Put another way, promoting low-severity fire in non-extreme years will reduce fuel loads and potentially decrease the probability of high-severity in fire extreme years.

It is recognized that low-severity fire consumes ladder and surface fuels $[95,96]$ and reduces the prevalence of shade-tolerant trees in many cases [97]. These changes to fuels and the structure and composition of vegetation have important implications in terms of the behavior and effects of subsequent fires $[17,19]$. For example, a recent study concluded that sites with a restored fire regime were more likely to retain conifer trees and less likely to convert to non-forest during a subsequent extreme fire event [40]. Moreover, low-severity fire often reinforces a pattern of low-severity fire in subsequent fire events $[18,59,98]$. Other beneficial aspects of low-severity fire are also evident. For example, low-severity fire increases the ability of trees to defend against bark beetle attacks [99]. These examples illustrate that low-severity fire increases resilience to subsequent abiotic and biotic disturbance events and that managers could consider taking active measures to promote low-severity fire in regions dominated by dry conifer forest. Our findings provide land managers with general principles for promoting low-severity fire. As such, our study is both timely and relevant given the 
increasing desire to allow fire to burn to achieve restoration objectives $[25,26,66]$ and the desire to avoid stand-replacing fire in dry forests in the southwestern USA $[39,100]$.

Acknowledgments: We acknowledge funding from the Joint Fire Science Program under project 15-1-03-20 and from the National Fire Plan through the Rocky Mountain Research Station. We also thank two anonymous reviewers for providing comments that considerably improved our manuscript.

Author Contributions: S.A.P. and S.Z.D. conceived and designed the study; M.H.P. extracted and produced the dataset; S.A.P. analyzed the data; S.A.P. wrote the paper with input from the other authors.

Conflicts of Interest: The authors declare no conflict of interest.

\section{References}

1. Agee, J.K. Fire Ecology of Pacific Northwest Forests; Island Press: Washington, DC, USA, 1993.

2. Margolis, E.Q.; Malevich, S.B. Historical dominance of low-severity fire in dry and wet mixed-conifer forest habitats of the endangered terrestrial Jemez Mountains salamander (Plethodon neomexicanus). For. Ecol. Manag. 2016, 375, 12-26. [CrossRef]

3. Touchan, R.; Allen, C.D.; Swetnam, T.W. Fire history and climatic patterns in ponderosa pine and mixed-conifer forests of the Jemez Mountains, northern New Mexico. In Fire Effects in Southwestern Forests: Proceedings of the Second La Mesa Fire Symposium; Allen, C.D., Ed.; General Technical Report RM-GTR-286; USDA Forest Service: Fort Collins, CO, USA, 1996; pp. 33-46.

4. Baisan, C.H.; Swetnam, T.W. Fire history on a desert mountain range: Rincon Mountain Wilderness, Arizona, USA. Can. J. For. Res. 1990, 20, 1559-1569. [CrossRef]

5. Swetnam, T.W.; Baisan, C.H. Historical fire regime patterns in the southwestern United States since AD 1700. In Fire Effects in Southwestern Forests: Proceedings of the Second La Mesa Fire Symposium; Allen, C.D., Ed.; General Technical Report RM-GTR-286; USDA Forest Service: Fort Collins, CO, USA; 1996; pp. 11-32.

6. Fulé, P.Z.; Covington, W.W.; Moore, M.M. Determining reference conditions for ecosystem management of southwestern ponderosa pine forests. Ecol. Appl. 1997, 7, 895-908. [CrossRef]

7. Covington, W.W.; Moore, M.M. Southwestern ponderosa forest structure: Changes since Euro-American settlement. J. For. Soc. Am. For. 1994, 92, 39-47.

8. Swetnam, T.W.; Allen, C.D.; Betancourt, J.L. Applied historical ecology: Using the past to manage for the future. Ecol. Appl. Ecol. Soc. Am. 1999, 9, 1189-1206. [CrossRef]

9. Savage, M.; Mast, J.N. How resilient are southwestern ponderosa pine forests after crown fires? Can. J. For. Res. 2005, 35, 967-977. [CrossRef]

10. Williams, J. Exploring the onset of high-impact mega-fires through a forest land management prism. For. Ecol. Manag. 2013, 294, 4-10. [CrossRef]

11. Mallek, C.; Safford, H.; Viers, J.; Miller, J. Modern departures in fire severity and area vary by forest type, Sierra Nevada and southern Cascades, California, USA. Ecosphere 2013, 4, 1-28. [CrossRef]

12. O'Connor, C.D.; Falk, D.A.; Lynch, A.M.; Swetnam, T.W. Fire severity, size, and climate associations diverge from historical precedent along an ecological gradient in the Pinaleño Mountains, Arizona, USA. For. Ecol. Manag. 2014, 329, 264-278. [CrossRef]

13. Fornwalt, P.J.; Huckaby, L.S.; Alton, S.K.; Kaufmann, M.R.; Brown, P.M.; Cheng, A.S. Did the 2002 Hayman Fire, Colorado, USA, burn with uncharacteristic severity. Fire Ecol. 2016, 12, 117-132. [CrossRef]

14. Chambers, M.E.; Fornwalt, P.J.; Malone, S.L.; Battaglia, M.A. Patterns of conifer regeneration following high severity wildfire in ponderosa pine-Dominated forests of the Colorado Front Range. For. Ecol. Manag. 2016, 378, 57-67. [CrossRef]

15. Rother, M.T.; Veblen, T.T. Limited conifer regeneration following wildfires in dry ponderosa pine forests of the Colorado Front Range. Ecosphere 2016, 7. [CrossRef]

16. Stevens-Rumann, C.S.; Kemp, K.B.; Higuera, P.E.; Harvey, B.J.; Rother, M.T.; Donato, D.C.; Morgan, P.; Veblen, T.T. Evidence for declining forest resilience to wildfires under climate change. Ecol. Lett. 2018, 21, 243-252. [CrossRef] [PubMed]

17. Coop, J.D.; Parks, S.A.; Mcclernan, S.R.; Holsinger, L.M. Influences of prior wildfires on vegetation response to subsequent fire in a reburned southwestern landscape. Ecol. Appl. 2016, 26, 346-354. [CrossRef] [PubMed] 
18. Coppoletta, M.; Merriam, K.E.; Collins, B.M. Post-fire vegetation and fuel development influences fire severity patterns in reburns. Ecol. Appl. 2016, 26, 686-699. [CrossRef] [PubMed]

19. Stevens-Rumann, C.; Morgan, P. Repeated wildfires alter forest recovery of mixed-conifer ecosystems. Ecol. Appl. 2016, 26, 1842-1853. [CrossRef] [PubMed]

20. Mast, J.N.; Fule, P.Z.; Moore, M.M.; Covington, W.W.; Waltz, A.E.M. Restoration of presettlement age structure of an Arizona ponderosa pine forest. Ecol. Appl. 1999, 9, 228-239. [CrossRef]

21. Brown, R.T.; Agee, J.K.; Franklin, J.F. Forest restoration and fire: Principles in the context of place. Conserv. Biol. 2004, 18, 903-912. [CrossRef]

22. Agee, J.K.; Skinner, C.N. Basic principles of forest fuel reduction treatments. For. Ecol. Manag. 2005, 211, 83-96. [CrossRef]

23. North, M.; Brough, A.; Long, J.; Collins, B.; Bowden, P.; Yasuda, D.; Miller, J.; Sugihara, N. Constraints on Mechanized Treatment Significantly Limit Mechanical Fuels Reduction Extent in the Sierra Nevada. J. For. 2015, 113, 40-48. [CrossRef]

24. Moritz, M.A.; Batllori, E.; Bradstock, R.A.; Gill, A.M.; Handmer, J.; Hessburg, P.F.; Leonard, J.; McCaffrey, S.; Odion, D.C.; Schoennagel, T.; et al. Learning to coexist with wildfire. Nature 2014, 515, 58. [CrossRef] [PubMed]

25. North, M.P.; Stephens, S.L.; Collins, B.M.; Agee, J.K.; Aplet, G.; Franklin, J.F.; Fulé, P.Z. Reform Forest Fire Management. Science 2015, 349, 1280-1281. [CrossRef] [PubMed]

26. Allen, C.D.; Savage, M.; Falk, D.A.; Suckling, K.F.; Swetnam, T.W.; Schulke, T.; Stacey, P.B.; Morgan, P.; Hoffman, M.; Klingel, J.T. Ecological restoration of southwestern ponderosa pine ecosystems: A broad perspective. Ecol. Appl. 2002, 12, 1418-1433. [CrossRef]

27. Zimmerman, T.; Frary, T.; Crook, S.; Fay, B.; Koppenol, P.; Lasko, R. Wildland fire use: Challenges associated with program management across multiple ownerships and land use situations. In Fuels Manag How to Meas Success; Andrews, P.L., Butl, B.W., Eds.; USDA For Serv Rocky Mt Res Station: Fort Collins, CO, USA, 2006; p. 809.

28. Krawchuk, M.A.; Haire, S.L.; Coop, J.; Parisien, M.-A.; Whitman, E.; Chong, G.; Miller, C. Topographic and fire weather controls of fire refugia in forested ecosystems of northwestern North America. Ecosphere 2016, 7. [CrossRef]

29. Camp, A.; Oliver, C.; Hessburg, P.; Everett, R. Predicting late-successional fire refugia pre-dating European settlement in the Wenatchee Mountains. For. Ecol. Manag. 1997, 95, 63-77. [CrossRef]

30. Parks, S.A.; Dillon, G.K.; Miller, C. A new metric for quantifying burn severity: The relativized burn ratio. Remote Sens. 2014, 6, 1827-1844. [CrossRef]

31. Rollins, M.G. LANDFIRE: A nationally consistent vegetation, wildland fire, and fuel assessment. Int. J. Wildl. Fire 2009, 18, 235-249. [CrossRef]

32. Olson, D.M.; Dinerstein, E. The Global 200: Priority ecoregions for global conservation. Ann. Mo. Bot. Gard. 2002, 89, 199-224. [CrossRef]

33. AdaptWest Project. Gridded Current and Projected Climate Data for North America at $1 \mathrm{~km}$ Resolution, Interpolated Using the ClimateNA v5.10 Software [Internet]. 2015. Available online: adaptwest.databasin.org (accessed on 2 April 2015).

34. Fick, S.E.; Hijmans, R.J. WorldClim 2: New 1-km spatial resolution climate surfaces for global land areas. Int. J. Climatol. 2017, 37, 4302-4315. [CrossRef]

35. Rollins, M.G.; Morgan, P.; Swetnam, T. Landscape-scale controls over 20th century fire occurrence in two large Rocky Mountain (USA) wilderness areas. Landsc. Ecol. 2002, 17, 539-557. [CrossRef]

36. Adams, D.K.; Comrie, A.C. The north American monsoon. Bull. Am. Meteorol. Soc. 1997, 78, $2197-2213$. [CrossRef]

37. Holden, Z.A.; Morgan, P.; Evans, J.S. A predictive model of burn severity based on 20-year satellite-inferred burn severity data in a large southwestern US wilderness area. For. Ecol. Manag. 2009, 258, 2399-2406. [CrossRef]

38. Swetnam, T.W.; Dieterich, J.H. Fire history of ponderosa pine forests in the Gila Wilderness, New Mexico. In Gen Tech Rep INT-GTR-182; US Department of Agriculture, Forest Service, Intermountain Forest and Range Experiment Station: Ogden, UT, USA, 1985.

39. Savage, M.; Mast, J.N.; Feddema, J.J. Double whammy: High-severity fire and drought in ponderosa pine forests of the Southwest. Can. J. For. Res. 2013, 43, 570-583. [CrossRef] 
40. Walker, R.B.; Coop, J.D.; Parks, S.A.; Trader, L. Fire regimes approaching historic norms reduce wildfire-facilitated conversion from forest to non-forest. Ecosphere 2018, in press.

41. Dillon, G.K.; Holden, Z.A.; Morgan, P.; Crimmins, M.A.; Heyerdahl, E.K.; Luce, C.H. Both topography and climate affected forest and woodland burn severity in two regions of the western US, 1984 to 2006. Ecosphere 2011, 2. [CrossRef]

42. Eidenshink, J.C.; Schwind, B.; Brewer, K.; Zhu, Z.-L.; Quayle, B.; Howard, S.M. A project for monitoring trends in burn severity. Fire Ecol. 2007, 3, 3-21. [CrossRef]

43. Key, C.H. Ecological and sampling constraints on defining landscape fire severity. Fire Ecol. 2006, 2, 34-59. [CrossRef]

44. Pettorelli, N.; Vik, J.O.; Mysterud, A.; Gaillard, J.-M.; Tucker, C.J.; Stenseth, N.C. Using the satellite-derived NDVI to assess ecological responses to environmental change. Trends Ecol. Evol. 2005, 20, 503-510. [CrossRef] [PubMed]

45. Chu, T.; Guo, X.; Takeda, K. Temporal dependence of burn severity assessment in Siberian larch (Larix sibirica) forest of northern Mongolia using remotely sensed data. Int. J. Wildl. Fire 2016, 25, 685-698. [CrossRef]

46. McDonald, A.J.; Gemmell, F.M.; Lewis, P.E. Investigation of the utility of spectral vegetation indices for determining information on coniferous forests. Remote Sens. Environ. 1998, 66, 250-272. [CrossRef]

47. Huete, A.; Didan, K.; Miura, T.; Rodriguez, E.P.; Gao, X.; Ferreira, L.G. Overview of the radiometric and biophysical performance of the MODIS vegetation indices. Remote Sens. Environ. 2002, 83, 195-213. [CrossRef]

48. Evans, I.S. General geomorphometry, derivatives of altitude, and descriptive statistics. In Spatial Analysis in Geomorphology; 1972; pp. 17-90. Available online: https://books.google.com/books/about/Spatial_ Analysis_in_Geomorphology.html?id=rvANAAAAQAAJ (accessed on 21 March 2018).

49. Flint, A.L.; Flint, L.E.; Hevesi, J.A.; Blainey, J.B. Fundamental concepts of recharge in the desert southwest: A regional modeling perspective. In Groundwater Recharge in a Desert Environment: The Southwestern United States; Hogan, J.F., Phillips, F.M., Scanlon, B.R., Eds.; 2004. Available online: https: / / agupubs.onlinelibrary. wiley.com/doi/book/10.1029/WS009 (accessed on 21 March 2018). [CrossRef]

50. Wang, T.; Hamann, A.; Spittlehouse, D.; Carroll, C. Locally downscaled and spatially customizable climate data for historical and future periods for North America. PLoS ONE 2016, 11, e0156720. [CrossRef] [PubMed]

51. Kane, V.R.; Cansler, C.A.; Povak, N.A.; Kane, J.T.; McGaughey, R.J.; Lutz, J.A.; Churchill, D.J.; North, M.P. Mixed severity fire effects within the Rim fire: Relative importance of local climate, fire weather, topography, and forest structure. For. Ecol. Manag. 2015, 358, 62-79. [CrossRef]

52. Parks, S.A.; Parisien, M.A.; Miller, C.; Dobrowski, S.Z. Fire activity and severity in the western US vary along proxy gradients representing fuel amount and fuel moisture. PLoS ONE 2014, 9, e99699. [CrossRef] [PubMed]

53. McKenzie, D.; Littell, J.S. Climate change and the eco-hydrology of fire: Will area burned increase in a warming western USA? Ecol. Appl. 2017, 27, 26-36. [CrossRef] [PubMed]

54. USDA Forest Service. MODIS Fire Detection GIS Data [Internet]. 2016. Available online: http:/ / activefiremaps. fs.fed.us/gisdata.php (accessed on 3 January 2016).

55. Abatzoglou, J.T.; Kolden, C.A.; Williams, A.P.; Lutz, J.A.; Smith, A.M.S. Climatic influences on interannual variability in regional burn severity across western US forests. Int. J. Wildl. Fire 2017, 26, 269-275. [CrossRef]

56. Keyser, A.; Westerling, A. Climate drives inter-annual variability in probability of high severity fire occurrence in the western United States. Environ. Res. Lett. 2017, 12, 065003. [CrossRef]

57. Huang, C.; Goward, S.N.; Masek, J.G.; Thomas, N.; Zhu, Z.; Vogelmann, J.E. An automated approach for reconstructing recent forest disturbance history using dense Landsat time series stacks. Remote Sens. Environ. 2010, 114, 183-198. [CrossRef]

58. Stevens-Rumann, C.; Prichard, S.; Strand, E.; Morgan, P. Prior wildfires influence burn severity of subsequent large fires. Can. J. For. Res. 2016, 46, 1375-1385. [CrossRef]

59. Parks, S.A.; Miller, C.; Nelson, C.R.; Holden, Z.A. Previous Fires Moderate Burn Severity of Subsequent Wildland Fires in Two Large Western US Wilderness Areas. Ecosystems 2014, 17, 29-42. [CrossRef]

60. Kane, V.R.; Lutz, J.A.; Alina Cansler, C.; Povak, N.A.; Churchill, D.J.; Smith, D.F.; Kane, J.T.; North, M.P. Water balance and topography predict fire and forest structure patterns. For. Ecol. Manag. 2015, 338, 1-13. [CrossRef]

61. R Core Team. R: A Language and Environment for Statistical Computing [Internet]; $\mathrm{R}$ foundation for Statistical Computing: Vienna, Austria, 2016. Available online: https:/ /www.r-project.org/ (accessed on 1 July 2017). 
62. Parks, S.A.; Holsinger, L.M.; Panunto, M.H.; Jolly, W.M.; Dobrowski, S.Z.; Dillon, G.K. High-severity fire: Evaluating its key drivers and mapping its probability across western US forests. Environ. Res. Lett. 2018, in press. [CrossRef]

63. Cansler, C.A.; McKenzie, D. Climate, fire size, and biophysical setting control fire severity and spatial pattern in the northern Cascade Range, USA. Ecol. Appl. Ecol. Soc. Am. 2014, 24, 1037-1056. [CrossRef]

64. Harvey, B.J.; Donato, D.C.; Turner, M.G. Drivers and trends in landscape patterns of stand-replacing fire in forests of the US Northern Rocky Mountains (1984-2010). Landsc. Ecol. 2016, 1-17. [CrossRef]

65. North, M.; Collins, B.M.; Stephens, S. Using fire to increase the scale, benefits, and future maintenance of fuels treatments. J. For. Soc. Am. For. 2012, 110, 392-401. [CrossRef]

66. Stephens, S.L.; Collins, B.M.; Biber, E.; Fulé, P.Z. US federal fire and forest policy: Emphasizing resilience in dry forests. Ecosphere 2016, 7. [CrossRef]

67. Tepley, A.J.; Thompson, J.R.; Epstein, H.E.; Anderson-Teixeira, K.J. Vulnerability to forest loss through altered postfire recovery dynamics in a warming climate in the Klamath Mountains. Glob. Chang. Biol. 2017, 23, 4117-4132. [CrossRef] [PubMed]

68. Fang, L.; Yang, J.; Zu, J.; Li, G.; Zhang, J. Quantifying influences and relative importance of fire weather, topography, and vegetation on fire size and fire severity in a Chinese boreal forest landscape. For. Ecol. Manag. 2015, 356, 2-12. [CrossRef]

69. Lydersen, J.M.; Collins, B.M.; Brooks, M.L.; Matchett, J.R.; Shive, K.L.; Povak, N.A.; Kane, V.R.; Smith, D.F. Evidence of fuels management and fire weather influencing fire severity in an extreme fire event. Ecol. Appl. 2017, 27, 2013-2030. [CrossRef] [PubMed]

70. Harris, L.; Taylor, A.H. Topography, Fuels, and Fire Exclusion Drive Fire Severity of the Rim Fire in an Old-Growth Mixed-Conifer Forest, Yosemite National Park, USA. Ecosystems 2015, 18, 1192-1208. [CrossRef]

71. Fang, L.; Yang, J.; White, M.; Liu, Z. Predicting Potential Fire Severity Using Vegetation, Topography and Surface Moisture Availability in a Eurasian Boreal Forest Landscape. Forests 2018, 9, 130. [CrossRef]

72. Birch, D.S.; Morgan, P.; Kolden, C.A.; Abatzoglou, J.T.; Dillon, G.K.; Hudak, A.T.; Smith, A.M.S. Vegetation, topography and daily weather influenced burn severity in central Idaho and western Montana forests. Ecosphere 2015, 6. [CrossRef]

73. Kennedy, M.C.; Johnson, M.C. Fuel treatment prescriptions alter spatial patterns of fire severity around the wildland-Urban interface during the Wallow Fire, Arizona, USA. For. Ecol. Manag. 2014, 318, 122-132. [CrossRef]

74. Mitchell, S.R.; Harmon, M.E.; O'connell, K.E.B. Forest fuel reduction alters fire severity and long-term carbon storage in three Pacific Northwest ecosystems. Ecol. Appl. 2009, 19, 643-655. [CrossRef] [PubMed]

75. Ager, A.A.; Finney, M.A.; Kerns, B.K.; Maffei, H. Modeling wildfire risk to northern spotted owl (Strix occidentalis caurina) habitat in Central Oregon, USA. For. Ecol. Manag. 2007, 246, 45-56. [CrossRef]

76. Finney, M.A.; McHugh, C.W.; Grenfell, I.C. Stand- and landscape-level effects of prescribed burning on two Arizona wildfires. Can. J. For. Res. 2005, 35, 1714-1722. [CrossRef]

77. Wimberly, M.C.; Cochrane, M.A.; Baer, A.D.; Pabst, K. Assessing fuel treatment effectiveness using satellite imagery and spatial statistics. Ecol. Appl. 2009, 19, 1377-1384. [CrossRef] [PubMed]

78. Preisler, H.K.; Riley, K.L.; Stonesifer, C.S.; Calkin, D.E.; Jolly, W.M. Near-term probabilistic forecast of significant wildfire events for the Western United States. Int. J. Wildl. Fire 2016, 25, 1169-1180. [CrossRef]

79. Preisler, H.K.; Westerling, A.L.; Gebert, K.M.; Munoz-Arriola, F.; Holmes, T.P. Spatially explicit forecasts of large wildland fire probability and suppression costs for California. Int. J. Wildl. Fire 2011, 20, 508-517. [CrossRef]

80. Estes, B.L.; Knapp, E.E.; Skinner, C.N.; Miller, J.D.; Preisler, H.K. Factors influencing fire severity under moderate burning conditions in the Klamath Mountains, northern California, USA. Ecosphere 2017, 8. [CrossRef]

81. Parks, S.A.; Holsinger, L.M.; Miller, C.; Parisien, M.-A. Analog-based fire regime and vegetation shifts in mountainous regions of the western US. Ecography 2018, in press. [CrossRef]

82. Kolden, C.A.; Lutz, J.A.; Key, C.H.; Kane, J.T.; van Wagtendonk, J.W. Mapped versus actual burned area within wildfire perimeters: Characterizing the unburned. For. Ecol. Manag. 2012, 286, 38-47. [CrossRef]

83. Kolden, C.A.; Abatzoglou, J.T.; Lutz, J.A.; Cansler, C.A.; Kane, J.T.; Van Wagtendonk, J.W.; Key, C.H. Climate contributors to forest mosaics: Ecological persistence following wildfire. Northwest Sci. 2015, 89, 219-238. [CrossRef] 
84. Meddens, A.J.H.; Kolden, C.A.; Lutz, J.A. Detecting unburned areas within wildfire perimeters using Landsat and ancillary data across the northwestern United States. Remote Sens. Environ. 2016, 186, 275-285. [CrossRef]

85. Kolden, C.A.; Bleeker, T.M.; Smith, A.; Poulos, H.M.; Camp, A.E. Fire Effects on Historical Wildfire Refugia in Contemporary Wildfires. Forests 2017, 8, 400. [CrossRef]

86. Haire, S.L.; Coop, J.D.; Miller, C. Characterizing Spatial Neighborhoods of Refugia Following Large Fires in Northern New Mexico USA. Land 2017, 6, 19. [CrossRef]

87. Berry, L.E.; Driscoll, D.A.; Stein, J.A.; Blanchard, W.; Banks, S.C.; Bradstock, R.A.; Lindenmayer, D.B. Identifying the location of fire refuges in wet forest ecosystems. Ecol. Appl. 2015, 25, 2337-2348. [CrossRef] [PubMed]

88. Morgan, P.; Keane, R.E.; Dillon, G.K.; Jain, T.B.; Hudak, A.T.; Karau, E.C.; Sikkink, P.G.; Holden, Z.A.; Strand, E.K. Challenges of assessing fire and burn severity using field measures, remote sensing and modelling. Int. J. Wildl. Fire 2014, 23, 1045-1060. [CrossRef]

89. Reinhardt, E.D.; Keane, R.E.; Brown, J.K. Modeling fire effects. Int. J. Wildl. Fire 2001, 10, 373-380. [CrossRef]

90. Parks, S.A. Mapping day-of-burning with coarse-resolution satellite fire-detection data. Int. J. Wildl. Fire 2014, 23, 215-223. [CrossRef]

91. Veraverbeke, S.; Sedano, F.; Hook, S.J.; Randerson, J.T.; Jin, Y.; Rogers, B.M. Mapping the daily progression of large wildland fires using MODIS active fire data. Int. J. Wildl. Fire 2014, 23, 655-667. [CrossRef]

92. Holsinger, L.; Parks, S.A.; Miller, C. Weather, fuels, and topography impede wildland fire spread in western US landscapes. For. Ecol. Manag. 2016, 380. [CrossRef]

93. Finney, M.A. The challenge of quantitative risk analysis for wildland fire. For. Ecol. Manag. 2005, 211, 97-108. [CrossRef]

94. Safford, H.D.; Stevens, J.T.; Merriam, K.; Meyer, M.D.; Latimer, A.M. Fuel treatment effectiveness in California yellow pine and mixed conifer forests. For. Ecol. Manag. 2012, 274, 17-28. [CrossRef]

95. Ryan, K.C.; Knapp, E.E.; Varner, J.M. Prescribed fire in North American forests and woodlands: History, current practice, and challenges. Front. Ecol. Environ. 2013, 11, s1. [CrossRef]

96. Vaillant, N.M.; Fites-Kaufman, J.A.; Stephens, S.L. Effectiveness of prescribed fire as a fuel treatment in Californian coniferous forests. Int. J. Wildl. Fire 2009, 18, 165-175. [CrossRef]

97. Becker, K.M.L.; Lutz, J.A. Can low-severity fire reverse compositional change in montane forests of the Sierra Nevada, California, USA? Ecosphere 2016, 7. [CrossRef]

98. Collins, B.M.; Miller, J.D.; Thode, A.E.; Kelly, M.; van Wagtendonk, J.W.; Stephens, S.L. Interactions Among Wildland Fires in a Long-Established Sierra Nevada Natural Fire Area. Ecosystems 2009, 12, 114-128. [CrossRef]

99. Hood, S.; Sala, A.; Heyerdahl, E.K.; Boutin, M. Low-severity fire increases tree defense against bark beetle attacks. Ecology 2015, 96, 1846-1855. [CrossRef] [PubMed]

100. Fulé, P.Z.; Swetnam, T.W.; Brown, P.M.; Falk, D.A.; Peterson, D.L.; Allen, C.D.; Aplet, G.H.; Battaglia, M.A.; Binkley, D.; Farrsi, C.; et al. Unsupported inferences of high-severity fire in historical dry forests of the western United States: Response to Williams and Baker. Glob. Ecol. Biogeogr. 2014, 23, 825-830. [CrossRef] 